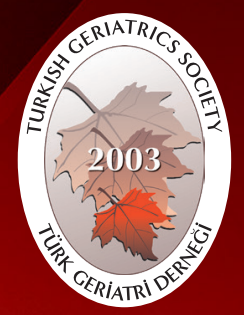

Turkish Journal of Geriatrics

DOI: 10.31086/tjgeri.2019.109

2019; 22(3): 331-339

- Emre ALTINKURT 1 (D)

- Adem UĞURLU² D

- Nevin KORKMAZ ${ }^{3}$ D

- Şerife Bayraktar ${ }^{1}$ D

\title{
COMPARISON OF INDICATIONS AND RESULTS OF PENETRATING KERATOPLASTY IN OLDER GERIATRIC PATIENTS WITH THOSE IN YOUNGER GERIATRIC PATIENTS
}

\section{Abstract}

Introduction: This study aimed to compare the indications and outcomes of penetrating keratoplasty in geriatric patients and to compare the younger geriatric patients with older geriatric patients.

Materials and Method: We evaluated the data of 489 eyes of 427 patients who underwent corneal transplantation surgery between August 2010 and July 2015 at a tertiary referral center in Turkey. We included 90 eyes of 81 patients aged $\geq 65$ years with at least 1 -year follow-up data were. The patients were divided into Groups 1 and 2 comprising patients aged 65-79 and $\geq 80$ years, respectively.

Results: Groups 1 and 2 included 66 and 24 eyes, respectively. Bullous keratopathy was the most common indication for penetrating keratoplasty surgery in both groups (Group $1=34.9 \%$, Group $2=66.7 \%, p=0.036$ ). The incidence of secondary glaucoma after surgery (Group $1=18.2 \%$, Group $2=15.6 \%, p=0.254$ ) and graft survival period (Group $1=29.9 \pm 15.8$ months, Group $2=26.7 \pm 13.2$ months, $p=0.374$ ) were not significantly different between the two groups. The graft rejection and failure rates between the groups were analyzed, and no difference was observed between them ( $p=0.531$, chi-squared $=0.392$ for graft rejection; $p=0.699$, chisquared $=0.150$ for graft failure)

Conclusion: Bullous keratopathy as an indication for penetrating keratoplasty is significantly more common in older geriatric patients. The outcomes of penetrating keratoplasty in older geriatric patients are as good as those in younger geriatric patients.

Keywords: Corneal transplantation; Graft survival; Graft rejection; Turkey; Penetrating keratoplasty

CORRESPONDANCE

\section{Emre ALTINKURT}

Istanbul University, Istanbul Faculty of Medicine,

Department of Ophthalmology, Istanbul, Turkey.

Phone: +902124142000

Fax: +902124142026

Mobile: +905323401048

e-mail: altinkurtemre@gmail.com

Received: 28/05/2019

Accepted: $21 / 08 / 2019$

Istanbul University,Istanbul Faculty of

Medicine, Department of Ophthalmology,

Istanbul, Turkey.

Binali Yildirim University,Mengucek Gazi

Training and Research Hospital , Department of Ophthalmology, Erzincan, Turkey.

${ }^{3}$ Mus Goverment Hospital, Department of Ophthalmology, Mus, Turkey.
ARASTIRMA

\section{ILERI YAŞ VE DAHA GENÇ GERIATRIK HASTALARDAKI PENETRAN KERATOPLASTI ENDIKASYONLARININ VE SONUÇLARININ KARŞILAŞTIRILMASI \\ $\ddot{\mathrm{O}}_{z}$}

Amaç: Geriatrik hastalarda, penetran keratoplasti endikasyonları ve sonuçların değerlendirmek, daha genç geriatrik hastalar ile daha yaşlı geriatrik hastaları karşılaştırmaktır.

Gereç ve Yöntem: Türkiye'deki bir üçüncü basamak referans merkezinde Ağustos 2010 ile Temmuz 2015 yılları arasında penetran keratoplasti cerrahisi uygulanan 427 hastanın 489 gözünün verileri incelendi. 65 yaș ve üzerinde cerrahi uygulanan ve cerrahi sonrası en az 1 yıl takip edilen 81 hastanın 90 gözü çalışmaya alındı. Hastalar 65-79 yaş arası Grup 1, 80 yaş ve üzeri Grup 2 olmak üzere iki gruba ayrıldı.

Bulgular: Grup 1'de 66 göz Grup 2'de ise 24 göz mevcuttu. Her iki grupta da en sık penetran keratoplasti cerrahisi endikasyonu büllöz keratopatiydi. ( Grup 1'de \%34,9, Grup 2 'de \%66,7 $\mathrm{p}=0,036$ ). Cerrahi sonrası sekonder glokom gelişimi (Grup $1 \% 18,2$,Grup $2 \% 15,6 \mathrm{p}=0,254$ ) ve greft sağkalımı ( Grup $129,9 \pm 15,8$ ay,Grup 2 26,7 $\pm 13,2$ ay, p=0,374) açısından iki grup arasında fark yoktu. Greft reddi ve yetmezliği açısından da her iki grup arasında istatistiksel fark saptanmadı. (Greft reddi için $p=0,531$ ki kare $=0,392$; greft yetmezliği için $p=0,699$ ki kare $=0,150$ ).

Sonuç: Daha yaşlı geriatrik hastalarda penetran keratoplasti endikasyonu olarak büllöz keratopati anlamlı bir şekilde daha yüksek oranda görülmektedir. Penetran keratoplasti cerrahisinin daha yaşı geriatrik hastalardaki başarısı daha genç geriatrik hastalardaki kadar iyidir.

Anahtar sözcükler: Korneal transplantasyon; Doku reddi; Greft ömrü; Türkiye; Penetran keratoplasti 


\section{INTRODUCTION}

The population of individuals aged $>65$ years is defined as elderly, and the proportion of the elderly population in Turkey was observed to be $8.3 \%$ in 2016 (1). When compared with the other age groups in the population, the fastest increase has been witnessed in elderly population aged $>75$ years (2). The ratio of people with visual disabilities in Turkey is 1.4\%; of these, $15.8 \%$ are aged $>65$ years (3) and according to the 1998 data in Southeast Turkey, corneal blindness accounted for $15 \%$ of all causes of blindness (4).

Chronic diseases, sensitivity to anesthetic agents and perioperative morbidity are more frequent in the elderly population aged $>75$ years $(5,6)$. Surgeons must perform a benefit-risk analysis before corneal transplantation to avoid unnecessary surgical procedures. Therefore, the graft survival period and frequency of complications and graft rejections should be known in elderly patients. Here, the outcomes in Turkish geriatric patients with corneal transplantation were investigated. Furthermore, we compared the results in older geriatric patients with those in younger geriatric patients.

\section{MATERIALS AND METHOD}

After obtaining the local ethics committee approval (2017/427) and written informed consent from all patients, the data of 489 eyes of 427 patients who underwent corneal transplantation between August 2010 and July 2015 at a tertiary referral center in Turkey were analyzed retrospectively. Of these, 90 eyes of 81 patients aged $>65$ years with at least 1-year follow-up data were included in the

Table 1. Preoperative systemic diseases of the patients.

\begin{tabular}{|c|c|c|c|c|}
\hline & $\begin{array}{r}\text { Group } 1 \\
n(\%)\end{array}$ & $\begin{array}{r}\text { Group } 2 \\
n(\%)\end{array}$ & $\begin{array}{l}\text { Total } \\
\mathrm{n}(\%)\end{array}$ & $p$ \\
\hline Hypertension & $41(69 \%)$ & $11(50 \%)$ & $52(64 \%)$ & 0.167 \\
\hline Diabetes mellitus & $22(37 \%)$ & $2(9 \%)$ & $24(29.6 \%)$ & $0.018^{*}$ \\
\hline $\begin{array}{l}\text { Coronary artery } \\
\text { disease }\end{array}$ & $10(17 \%)$ & - & 10 (12.3\%) & - \\
\hline Chronic renal failure & $3(5 \%)$ & - & $3(3.7 \%)$ & - \\
\hline $\begin{array}{l}\text { Benign prostatic } \\
\text { hyperplasia }\end{array}$ & $3(5 \%)$ & - & $3(3.7 \%)$ & - \\
\hline $\begin{array}{l}\text { Chronic obstructive } \\
\text { pulmonary disease }\end{array}$ & $2(3.4 \%)$ & $1(4.5 \%)$ & $3(3.7 \%)$ & 0.256 \\
\hline Hypothyroidism & $2(3.4 \%)$ & - & $2(2.5 \%)$ & - \\
\hline Hyperlipidemia & $2(3.4 \%)$ & - & $2(2.5 \%)$ & - \\
\hline Hepatitis C & $2(3.4 \%)$ & - & $2(2.5 \%)$ & - \\
\hline Heart rhythm disorders & - & $2(9 \%)$ & $2(2.5 \%)$ & - \\
\hline Osteoporosis & - & $2(9 \%)$ & $2(2.5 \%)$ & - \\
\hline Asthma & $1(1.7 \%)$ & - & $1(1.2 \%)$ & - \\
\hline Rheumatoid arthritis & $1(1.7 \%)$ & - & $1(1.2 \%)$ & - \\
\hline
\end{tabular}

*Significantly different 
study. The patients were separated into Groups 1 and 2 comprising patients aged $65-79$ and $\geq 80$ years, respectively.

All surgeries were performed using a standard technique, and the donor corneal tissues were provided by the eye bank at the tertiary referral center. Donor-recipient age matching was not conducted. All surgeries were penetrating keratoplasties performed under general anesthesia. Donor buttons were cut $0.25-\mathrm{mm}$ or 0.50-mm larger than the recipient bed using Barron radial vacuum trephines and Barron punches. The

Table 2. Indications for corneal transplantation surgery in the geriatric patients.

\begin{tabular}{|c|c|c|c|}
\hline & $\begin{array}{r}\text { Group } 1 \\
n(\%)\end{array}$ & $\begin{array}{r}\text { Group } 2 \\
n(\%)\end{array}$ & p \\
\hline BULLOUS KERATOPATHY & 27 (40.9\%) & $16(66.7 \%)$ & $0.036^{*}$ \\
\hline Pseudophakic bullous keratopathy & 23 & 15 & \\
\hline Aphakic bullous keratopathy & 4 & 1 & \\
\hline PREVIOUS GRAFT FAILURE & $18(27.3 \%)$ & $3(12.5 \%)$ & 0.167 \\
\hline Pseudophakic bullous keratopathy & 5 & 1 & \\
\hline $\begin{array}{l}\text { Corneal scar } \\
\qquad \begin{array}{r}\text { due to herpetic keratitis } \\
\text { due to ocular trauma }\end{array}\end{array}$ & $\begin{array}{l}5 \\
4 \\
1\end{array}$ & $\begin{array}{l}- \\
-\end{array}$ & \\
\hline Keratoconus & 4 & - & \\
\hline $\begin{array}{r}\text { Corneal dystrophy } \\
\text { Fuchs endothelial dystrophy } \\
\text { Granular dystrophy } \\
\text { Lattice corneal dystrophy }\end{array}$ & $\begin{array}{l}4 \\
1 \\
2 \\
1\end{array}$ & $\begin{array}{l}2 \\
1 \\
- \\
1\end{array}$ & \\
\hline CORNEAL SCAR & $12(18.2 \%)$ & $3(12.5 \%)$ & 0.522 \\
\hline due to herpetic keratitis & 9 & - & \\
\hline due to ocular trauma & 1 & - & \\
\hline due to nonherpetic keratitis & 2 & 3 & \\
\hline CORNEAL DYSTROPHY & $6(9.1 \%)$ & $1(4.2 \%)$ & 0.441 \\
\hline Fuchs endothelial dystrophy & 5 & - & \\
\hline Posterior polymorphous dystrophy & 1 & 1 & \\
\hline CORNEAL DEGENERATION & $2(3.03 \%)$ & - & - \\
\hline CORNEAL ECTASIA & $1(1.5 \%)$ & $1(4.2 \%)$ & 0.450 \\
\hline Pellucid marginal degeneration & 1 & - & \\
\hline Keratoconus & - & 1 & - \\
\hline TOTAL & $66(100 \%)$ & $24(100 \%)$ & \\
\hline
\end{tabular}

*Significantly different 
Figure 1. Evaluation of graft rejection in the geriatric patients who underwent penetrating keratoplasty with a KaplanMeier survival analysis $(p=0.531$, chi-squared $=0.392$.

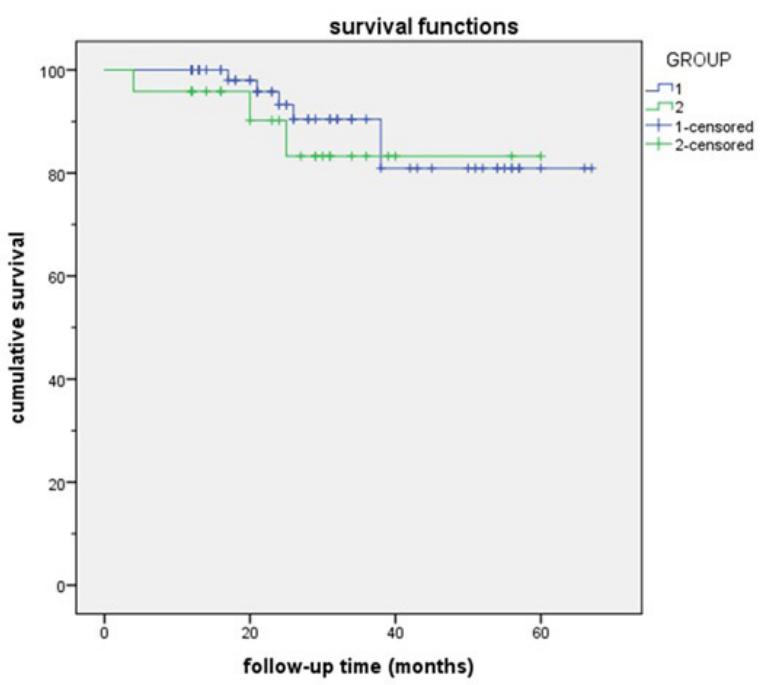

Figure 2. Evaluation of graft failure in the geriatric patients who underwent penetrating keratoplasty with a KaplanMeier survival analysis $(p=0.699$, chi-squared $=0.150$ ).

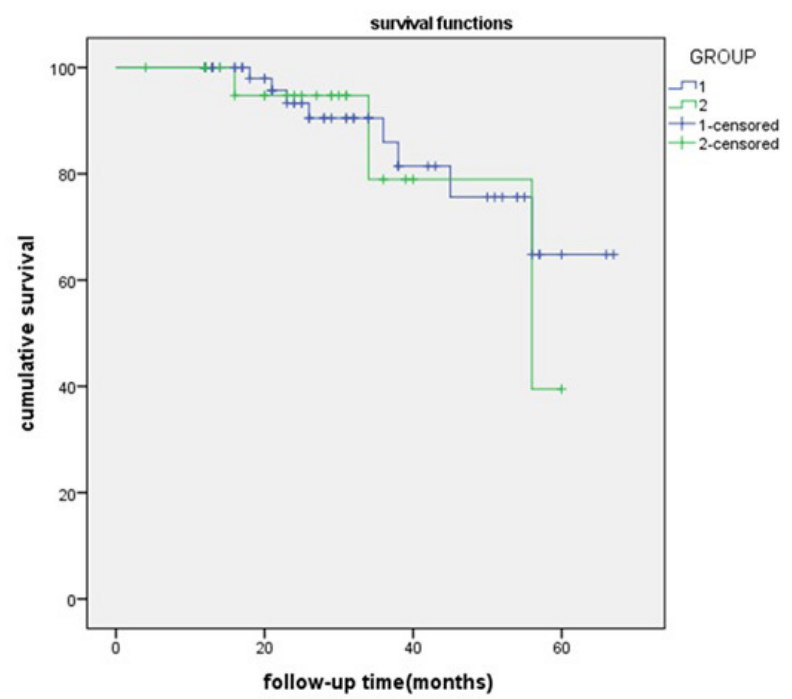

donor tissues were attached to the host tissue with interrupted or running 10-0 nylon sutures or a combination of both.

Postoperatively, $0.3 \%$ tobramycin was used four times daily for 10 days, and $1 \%$ prednisolone sodium phosphate was initiated 6-8 times daily and tapered off over 10-15 months. The sutures were removed when the sutures loosened or vascularization of the host cornea occured. The routine suture removal was performed between 12 and 30 months after the surgery. At each visit, the graft clarity was assessed by biomicroscopic examination, and the visual acuity was measured. The intraocular pressure was measured using an applanation tonometer. The irreversible loss of clarity of the graft for a minimum of 3 sequential months was defined as graft failure (7). Development of subepithelial infiltrates, keratic precipitates, endothelial rejection line, an anterior chamber reaction, or a corneal edema in a previously clear graft was defined as graft rejection (8). In the event of allograft rejection, $1 \%$ prednisolone sodium phosphate was initiated every hour.

The chi-squared test was used to compare the nominal data, and the Kaplan-Meier survival analysis test was used to compare graft survival and rejection among the groups. An independent t-test was used to compare the follow-up period between the groups, Pearson correlation analysis was used to evaluate the correlations between data in both groups, and The Statistical Package for the Social Sciences version 22.0 (SPSS Inc., Chicago, IL, USA) was used to analyze the statistical tests, with a $p$ value $<0.05$ considered to be significant.

\section{RESULTS}

Geriatric patients accounted for $18.4 \%$ of all patients undergoing corneal transplantation between August 2010 and July 2015. Groups 1 and 2 comprised 66 (73\%) and 24 (27\%) eyes, respectively. The mean age of the patients undergoing surgery was $70.4 \pm 3.5$ and $81.5 \pm 2$ 
Table 3. The corneal transplantation outcomes and graft survival rates of the geriatric patients.

\begin{tabular}{|c|c|c|c|c|}
\hline & Group 1 & Group 2 & Total & $p$ value \\
\hline Mean BCVA before surgery (logMAR) & $1.6 \pm 0.51$ & $1.85 \pm 0.4$ & $1.67 \pm 0.5$ & $0.040^{\star}$ \\
\hline Final mean BCVA after surgery (logMAR) & $1.06 \pm 0.67$ & $1.07 \pm 0.63$ & $1.06 \pm 0.66$ & 0.938 \\
\hline Highest mean BCVA after surgery (logMAR) & $0.7 \pm 0.5$ & $0.82 \pm 0.54$ & $0.73 \pm 0.5$ & 0.324 \\
\hline Graft rejection & $6 / 66(9.1 \%)$ & $3 / 24(12.5 \%)$ & $9 / 90(10 \%)$ & 0.634 \\
\hline Graft failure & $8 / 66(12.1 \%)$ & $3 / 24(12.5 \%)$ & $11 / 90(12.2 \%)$ & 0.961 \\
\hline Secondary glaucoma after surgery & $12 / 66(18.2 \%)$ & $2 / 24(8.3 \%)$ & $14 / 90(15.6 \%)$ & 0.254 \\
\hline Cataract after surgery & $3 / 66(4.5 \%)$ & $0 / 66(0 \%)$ & $3 / 90(3.3 \%)$ & - \\
\hline Keratitis after surgery & $3 / 66(4.5 \%)$ & $0 / 66(0 \%)$ & $3 / 90(3.3 \%)$ & - \\
\hline Retinal detachment after surgery & $1 / 66(1.5 \%)$ & $0 / 66(0 \%)$ & $1 / 90(1.1 \%)$ & - \\
\hline 1-year graft survival rates & $100 \%$ & $100 \%$ & & \\
\hline 2-year graft survival rates & $93.3 \pm 0.037 \%$ & $94.7 \pm 0.051 \%$ & & \\
\hline 3-year graft survival rates & $85.9 \pm 0.062 \%$ & $78.9 \pm 0.150 \%$ & & \\
\hline 5-year graft survival rates & $64.8 \pm 0.125 \%$ & $39.5 \pm 0.289 \%$ & & \\
\hline Mean graft survival rate during the mean follow-up period & $90.5 \pm 0.046 \%$ & $94.7 \pm 0.051 \%$ & & \\
\hline
\end{tabular}

*Significantly different, BCVA: best corrected visual acuity.

years and the mean follow-up period was $31.65 \pm 16.66$ and $28.25 \pm 13.17$ months in Groups 1 and 2, respectively. No significant difference was observed between the study groups with regard to the sex $(p=0.567)$ or the follow-up period $(p=0.514)$.

The preoperative systemic diseases of the patients are shown in Table 1. In Groups 1 and 2, 22 (37.3\%) and 2 (9.1\%) patients had three or more systemic diseases, respectively; however, the difference was not statistically significant $(p=0.254)$.

The indications for corneal transplantation in the geriatric patients are listed in Table 2. Bullous keratopathy was the most common indication for transplantation surgery in both groups and was diagnosed significantly more often in Group 2 than in Group 1 ( $p=0.036$ ).

No significant difference was observed between the two groups with regard to the coexisting ocular findings before corneal transplantation, which were cataract (Group 1: 34.9\%; Group 2: 20.8\%), glaucoma (Group 1: 38\%; Group 2: 20.8\%), blepharitis (Group 1: 27.3\%; Group 2: 29.2\%), dry eyes (Group 1: 19.7\%; Group 2: 16.7\%), and retinopathy (Group 1: 9.1\%; Group 2: 4.2\%). Posterior chamber intraocular lenses (PCIOLs) were observed in $62.1 \%$ and $79.2 \%$ of eyes in Groups 1 and 2, respectively, and were the most 
common finding in both groups.

Nineteen cases (28.8\%) in Group 1 and 8 cases (33.3\%) in Group 2 underwent surgeries combined with corneal transplantation $(p=0.677)$; however, no significant difference was observed between both groups. Phacoemulsification and PClOL implantation were observed in 9 eyes in Group 1 and 2 eyes in Group 2 and were the most common surgeries combined with the corneal transplantation.

Ten eyes (15.2\%) in Group 1 and three eyes (12.5\%) in Group 2 underwent additional postoperative surgeries, with no statistically significant difference between the two groups $(p=0.752)$.

The outcomes of corneal transplantation in the geriatric patients are shown in Table 3. No significant difference was observed between the groups with regard to graft rejection using the Kaplan-Meier survival analysis test $(p=0.531$, chi-squared=0.392) (Figure 1). In this study, the overall average graft survival period was $29.1 \pm 15.2$ months, whereas it was $29.9 \pm 15.8$ months in Group 1 and $26.7 \pm 13.2$ months in Group 2. No statistically significant difference was noted between the two groups (independent t-test, $p=0.374$ ). The graft survival rates for each year are shown in Table 3.

Similarly, no difference was detected between the study groups with regard to the graft failure rate using the Kaplan-Meier survival analysis $(p=0.699$, chi-squared=0.150) (Figure 2). In addition, the patients who underwent surgery for bullous keratopathy were evaluated. No differences were observed in terms of the graft rejection ( $p=0.516$, chi-squared $=0.422)$ and failure $(p=0.702$, chisquared=0.146) between the two groups using the Kaplan-Meier survival analysis test.

\section{DISCUSSION}

In this study, all the performed corneal transplantation surgeries were penetrating keratoplasties. Partial thickness surgeries have been increasing worldwide. Although endothelial keratoplasty is the most common technique preferred in geriatric patients in developed countries (9), penetrating keratoplasty was the only technique selected for these geriatric patients because of the absence of precut tissue facilities for descemet stripping automated endothelial keratoplasty .

Endothelial disorders were the main cause and most common indication of corneal transplantations in the geriatric patients in our study, which is consistent with the literature (10-12); moreover, they were diagnosed significantly more often in Group $2(p=0.036)$. Previous graft failure was the second most common indication, and corneal ectasia was the least common indication in both groups.

Recently, advances in the surgical techniques for cataract surgery have improved the rate of endothelial cell loss and enhanced the optical outcomes of patients (13). This justifies the lesser number of bullous keratopathy cases in Group 1 than in Group 2.

In the study by Duman et al., Fuchs' endothelial dystrophy (41\%) was the leading indication, and pseudophakic bullous keratopathy (26\%) was the second most frequent indication for corneal transplantation in geriatric patients (11). However, Fuchs' endothelial dystrophy was diagnosed only in Group 1 (7.6\%) in our study. This difference can be explained by the genetic differences between the two study populations. Western regions such as the United States, Canada, and Europe have reported more Fuchs' endothelial dystrophy cases than the Middle East, Asia, Oceania, and South America (14).

Corneal transplantation considerably improved postoperative vision in both groups, with no statistically significant difference between them. The highest mean BCVA after surgery was $0.7 \pm 0.5$ logMAR in Group 1 and $0.82 \pm 0.54 \log M A R$ in Group 2 ( $p=0.324)$. 
No significant difference was observed between the groups with regard to secondary glaucoma $(p=0.123)$; however, 12 eyes (18.2\%) in Group 1 and 2 eyes (8.3\%) in Group 2 had secondary glaucoma. Karadag et al. reported that the prevalence of glaucoma after penetrating keratoplasty was $16.6 \%$ in a study regarding the Turkish population, which is consistent with our study (15). However, Duman et al. reported that glaucoma following corneal transplantation was more frequent in patients aged $>80$ years than in those aged 65-80 years (11). No significant difference was observed between the groups with regard to graft rejection ( $p=0.531$, chi-squared $=0.392$ ) and failure $(p=0.699$, chi-squared $=0.150)$ (Figures 1 and 2). In addition, No difference was observed between the two subgroups that underwent surgery for bullous keratopathy diagnosis with regard to graft rejection ( $p=0.516$, chi-squared $=0.422$ ) and failure $(p=0.702$, chi-squared $=0.146)$.

In the current study, the overall average graft survival period was $29.1 \pm 15.2$ months; it was $29.9 \pm 15.8$ months in Group 1 and $26.7 \pm 13.2$ months in Group 2, with no significant difference between them ( $p=0.374$, independent t-test). The graft survival rate of the corneal transplantations at 1 year was $100 \%$ in both groups. The $2-, 3-$, and 5 -year graft survival rates were $93.3 \%, 85.9 \%$, and $64.8 \%$ in Group 1 and $94.7 \%, 78.9 \%$, and $39.5 \%$ in Group 2, respectively. The 1-year survival rates of penetrating keratoplasty in the literature were 80\%-93.5\%; however, these were dependent on the indication for the transplantation $(16,17)$. The 5 -year survival probability of the penetrating keratoplasty in the literature is $83.0 \%$; it is more favorable in ectasia cases (96.0\%) and least favorable in pseudophakic corneal edema (67.0\%) and regraft (64.0\%) cases (8).

An older recipient age has been investigated in terms of the graft failure and rejection in previous studies, and different results have been reported. Williams et al. and Inoue et al. suggested that the relative risks of graft failure in recipients aged $>50$ years were 3.03 and 2.38 , respectively $(18,19)$. In the Singapore Corneal Transplant Study (20), a poorer prognosis was reported in older patients, which was similar to that in the study by Williams et al. However, in the cornea-donor study (21), the patient's age was not associated with the risk of graft failure, whereas Vail et al. reported that the risk of graft rejection was decreased with increasing recipient age (22).

Duman et al. compared recipients aged $65-80$ years with those aged $>80$ years (11); no significant difference was observed in terms of the graft survival and rejection rates. The recipient age was evaluated in another study (10), which reported that the corneal graft survival decreases significantly in recipients aged $\geq 60$ years. However, the difference in the survival between the groups aged 60-79 and $>80$ years was not significant.

In terms of the total number of additional postoperative surgeries, no significant difference was observed between the groups $(p=0.752)$. Among all 90 eyes, 3 (3.3\%) had cataracts and 1 (1.1\%) had retinal detachment, with no incidence of endophthalmitis after corneal transplantation. In the literature, the incidence of infectious keratitis following penetrating keratoplasty in high-income countries was $1.76 \%-4.9 \%$ (23), whereas 3 eyes (3.3\%) with keratitis were observed in our study.

This study has some limitations; for example, the data was retrospective, and the number of cases was small. In addition, patients with three or more preoperative systemic diseases (37.3\% vs. 9.1\%, $p=0.254)$, and those preoperative glaucoma was more frequent in Group 1 (38\% vs. $20.8 \%, p=0.129)$ than in Group 2, although the difference was statistically insignificant. Moreover, the indication of previous graft failure in Group 1 was higher than that in Group 2 (27.3\% vs. $12.5 \%$, $\mathrm{p}=0.167)$. However, the difference was statistically insignificant.

Both preoperative glaucoma and a repeat penetrating corneal transplantation are risk factors for graft failure $(21,24)$. When the surgeons 
were planning corneal transplantation in patients in Group 2, they may have selected those with less systemic diseases and without glaucoma or previous corneal transplantation. In addition, the patients with three or more systemic diseases may not be able to visit the corneal clinics because of their impaired health. Therefore, this may have resulted in a bias regarding the patient selection criteria.

In conclusion, this study revealed that penetrating keratoplasty improves the postoperative vision in geriatric patients, with no significant difference between younger geriatric

\section{REFERENCES}

1. Turkish Statistical Institute Newsletter, Elderly Statistics, 2016. [Internet] Available from: http:// www.tuik.gov.tr/PreHaberBultenleri.do?id=24644. Accessed 11.04.2017.

2. Turkish Statistical Institute Newsletter, Elderly Statistics, 2014. [Internet] Available from: http:// www.tuik.gov.tr/PreHaberBultenleri.do?id=18620 Accessed 11.04.2017.

3. Turkish Statistical Institute, Survey on Problems and Expectations of Disabled People, 2010. [Internet] Available from: http://www.turkstat.gov.tr/Kitap. do?metod=KitapDetay\&KT_ID=1\&KITAP_ID =244. Accessed 11.04.2017.

4. Negrel AD, Minassian DC, Sayek F. Blindness and low vision in southeast Turkey. Ophthalmic Epidemiol 1996;3(3):127-34. (PMID:8956316).

5. Shruthi R, Jyothi R, Pundarikaksha HP, Nagesh GN, Tushar TJ. A study of medication compliance in geriatric patients with chronic illnesses at a tertiary care hospital. J Clin Diagn Res 2016;10(12):FC40-3. (PMID:28208878).

6. Kanonidou Z, Karystianou G. Anesthesia for the elderly. Hippokratia 2007;11:175-7. (PMID:19582189).

7. Ang M, Mehta JS, Sng CC, Htoon HM, Tan DT. Indications, outcomes, and risk factors for failure in tectonic keratoplasty. Ophthalmology 2012;119(7):1311-9. (PMID:22541633).

8. Fasolo A, Capuzzo C, Fornea M, et al. Risk factors for graft failure after penetrating keratoplasty: 5-year follow-up from the corneal transplant epidemiological study. Cornea 2011;30(12):1328-35. (PMID:21926910). patients and older geriatric patients in terms of the graft survival and postoperative complications. However, further prospective studies with larger samples may yield better results.

\section{FUNDING:}

This study was not funded.

\section{DECLARATION OF INTEREST:}

No conflicting relationships exist for any of the authors.

9. Frigo AC, Fasolo A, Capuzzo C, et al. Corneal transplantation activity over 7 years: changing trends for indications, patient demographics and surgical techniques from the Corneal Transplant Epidemiological Study (CORTES). Transplant Proc 2015;47(2):528-35. (PMID:25769602).

10. Williams KA, Muehlberg SM, Lewis RF, Coster DJ. Influence of advanced recipient and donor age on the outcome of corneal transplantation. Australian Corneal Graft Registry. Br J Ophthalmol 1997;81(10):835-9. (PMID:9486022).

11. Duman F, Kosker M, Suri K, et al. Indications and outcomes of corneal transplantation in geriatric patients. Am J Opthalmol 2013;156(3):600-7. (PMID:23769195).

12. Ondas O, Keles S, Bozkurt E. Aetiology, outcomes and prognosis of penetrating keratoplasty performed on patients aged above 65 years. Turk J Geriatr 2019;22(1):56-65.

13. Rosado-Adames N, Afshari NA. The changing fate of the corneal endothelium in cataract surgery. Curr Opin Ophthalmol 2012;23(1):3-6. (PMID:22134364).

14. Eghrari AO, Gottsch JD. Fuchs' corneal dystrophy. Expert Rev Ophthalmol 2010;5(2):147-59. (PMID:20625449).

15. Karadag $O$, Kugu S, Erdogan G, Kandemir B, Eraslan OS, Dogan OK. Incidence of and risk factors for increased intraocular pressure after penetrating keratoplasty. Cornea 2010;29(3):278-82. (PMID:23275910).

16. Patel HY, Ormonde $\mathrm{S}$, Brookes $\mathrm{NH}$, et al. The New 
Zealand National Eye Bank: Survival and visual outcome 1 year after penetrating keratoplasty. Cornea 2011;30(7):760-4. (PMID:21282990).

17. Pan Q, Li X, Gu Y. Indications and outcomes of penetrating keratoplasty in a tertiary hospital in the developing world. Clin Exp Ophthalmol 2012;40(3):232-8. (PMID:21575124).

18. Williams KA, Roder D, Esterman A, Muehlberg SM, Coster DJ. Factors predictive of corneal graft survival. Report from the Australian Corneal Graft Registry. Ophthalmology 1992;99(3):403-14. (PMID:1565452).

19. Inoue K, Amano S, Oshika T, Tsuru T. Risk factors for corneal graft failure and rejection in penetrating keratoplasty. Acta Ophthalmol Scand 2001;79(3):2515. (PMID:11401633).

20. Tan DT, Janardhanan $P$, Zhou $H$, et al. Penetrating keratoplasty in Asian eyes: The Singapore Corneal
Transplant Study. Ophthalmology 2008;115(6):975-82. (PMID:18061267).

21. Sugar A, Tanner JP, Dontchev M, et al. Recipient risk factors for graft failure in the cornea donor study. Ophthalmology 2009;116(6):1023-8. (PMID:19395036).

22. Vail A, Gore SM, Bradley BA, Easty DL, Rogers CA, Armitage WJ. Conclusions of the corneal transplant follow up study. Collaborating Surgeons. $\mathrm{Br} \mathrm{J}$ Ophthalmol 1997; 81(8):631-6. (PMID:9349147).

23. Davila JR, Mian SI. Infectious keratitis after keratoplasty. Curr Opin Ophthalmol 2016;27(4):358-66. (PMID:27054815).

24. Al-Mezaine $H$, Wagoner MD. Repeat penetrating keratoplasty: indications, graft survival, and visual outcome. $\mathrm{Br} J$ Ophthalmol 2006; 90(3):324-7. (PMID:16488955). 